\title{
From chlorophyll a towards bacteriochlorophyll a: excited-state processes of modified pigments
}

\author{
K. Teuchner*, H. Stiel, D. Leupold, I. Katheder ${ }^{1}$, H. Scheer ${ }^{1}$ \\ Max-Born-Institut für Nichtlineare Optik und Kurzzeitspektroskopie. Rudower Chaussee 6, D-12474 Berlin, German."
}

\begin{abstract}
By means of fluorescence spectroscopy and nonlinear absorption experiments, excited-state processes of the modified pigments [3-acetyl]-chlorophyll a, [3 $\left.{ }^{1}-\mathrm{OH}\right]$-bacteriochlorophyll a and [3-vinyl]-bacteriochlorophyll a were investigated and compared with those of chlorophyll a and bacteriochlorophyll a.
\end{abstract}

\section{Introduction}

Excited-state properties of pigments of higher plant and bacterial photosynthesis and of related modified pigments are of multifarious interest, e.g., as basic information for molecular (excited-state) engineering, also with respect to the photophysical processes of photosynthesis and their alteration in case of pigment exchange, as well as with respect to photochemistry in view of photodynamic therapy. Some were published recently, especially those of chlorophyll a, bacteriochlorophyll a, chlorophyll $\mathrm{b}$ and 20-chloro-chlorophyll a $[1,2]$. For a more detailed characterization of the effect of the transit chlorophyll a (Chla) $\rightarrow$ bacteriochlorophyll a (BChla) on the excited state properties, further fluorescence spectroscopy and nonlinear absorption studies were carried out with the modified pigments [3-acetyl]-Chla and [3-vinyl]-BChla.

\footnotetext{
* Corresponding author.

' Botanisches Institut der Universität München. Menzinger Str. 67, D-80638 München, Germany.
}

because the structural differences between Chla and BChla involve the degree of unsaturation (chlorin versus bacteriochlorin) as well as a changed substituent at C-3 (vinyl versus acetyl), these modified pigments characterize two ways of this transit. Also investigated was the $\left[3^{1}-\mathrm{OH}\right]-\mathrm{BChla}$, in which the C-3 substituent has no double bonds capable of conjugation with the macrocycle.

\section{Experimental}

The pigments investigated were prepared as described in [3]. The solvent diethylether was of UVASOL grade. Fluorescence spectra, emission cross-sections, quantum yields, decay times and ISC rates were determined according to Ref. [4] and literature cited therein. For determination of the fluorescence quantum yields of [3-vinyl]-BChla and $\left[3^{1}-\mathrm{OH}\right]-\mathrm{BChla}$, the reference compound was BChla $\left(\phi_{\mathbf{F}}=0.19,[5]\right)$, whereas the quantum yield of [3-acetyl]-Chla was calibrated against Chla $\left(\phi_{\mathrm{F}}=0.32,[1]\right)$. The nonlinear absorption apparatus and the data processing were described in 
Ref [6]. Excitation was performed by a dye laser pumped by a nitrogen laser (pulse duration: $1.4 \mathrm{ns,}$ pulse energy: $6-12 \mu \mathrm{J}$ ). For further details cf. [1].

\section{Results and discussion}

\subsection{Fluorescence, internal conversion and intersys- tem crossing}

In Table 1 the excited state deactivation parameters are summarized. The radiative lifetime $\left(1 / k_{\mathrm{R}}\right)$ of all pigments investigated is approximately the same. The differences in the fluorescence lifetime $(\tau)$ are mainly caused by intersystem crossing (ISC). Change to a $\mathrm{C} 7-\mathrm{C} 8$ single bond gives increased ISC in both cases (Chla $\rightarrow$ [3-vinyl]-BChla; [3acetyl]-Chla $\rightarrow$ BChla), whereas in cases of a vinyl $\rightarrow$ acetyl transition the ISC change within the same macrocycle conjugation system in minor. Our results for BChla differ from that of Connolly et al. $[5]$, who discussed smaller ISC yields $\left(\phi_{\text {isc }} \approx 0.4\right)$ obtained from theoretical calculations, and correlate with earlier experimental results of Gurinovich et al. [7]. The rate constants for internal conversion $\left(k_{\mathrm{ic}}\right)$ are about one order of magnitude lower than for intersystem crossing and do not differ markedly. An exception is $\left[3^{1}-\mathrm{OH}\right]$-BChla where $k_{\mathrm{ic}}$ is en- larged by a factor of about two. Probably, this could be explained by the loss of conjugation of the C-3 substituent with the macrocycle leading to an additional energy dissipation by the rotation of this group.

\subsection{Excited-state absorptions}

The values for the excited-singlet-state absorption cross-sections (cf. bar graphs in Figs. 1 and 2) were calculated by curve simulation of intensitydependent transmission curves measured for distinct excitation wavelengths. For this an energy level scheme with two absorption steps in the singlet and one in the triplet system (cf. inset of Fig. 1) was utilized considering the rate constants of Table 1. The Franck-Condon relaxation (FC) and the triplet parameters were generally set to $k_{\mathrm{FC}}=1 \times 10^{12} \mathrm{~s}^{-1}, \quad k_{\mathrm{ph}}=1 \times 10^{4} \mathrm{~s}^{-1}$, $\sigma_{\mathrm{T}}<5 \times 10^{-17} \mathrm{~cm}^{2}, \quad k_{\mathrm{Tn}}=1 \times 10^{12} \mathrm{~s}^{-1}$. Furthermore, it proves necessary to consider the crosssections for stimulated emission $\sigma_{\mathrm{em}}$ at least for the long-wavelength side of the $S_{1}$ absorption band $\left(\lambda(\mathrm{nm}) / \sigma_{\mathrm{em}} \times 10^{16}\left(\mathrm{~cm}^{2}\right)\right.$ : Chla $-666 / 2.6,669 / 2.5$; [3-acetyl]-Chla - 677/2.3, 686/3.4; [3'-OH]-BChla - 730/2.3, 734/3, 738/3.3, 740/3.3; [3-vinyl]-BChla - 750/2.5, 755/2.9, 760/3, 770/2.2; BChla - 775/3.8, $780 / 4.3,785 / 4.4,790 / 3.6)$.

Table 1

Excited-state deactivation channels of Chla, [3-acetyl]-Chla, [3 $\left.{ }^{1}-\mathrm{OH}\right]-\mathrm{BChla},[3-$ vinyl]-BChla and $\mathrm{BChla}$ in diethylether

\begin{tabular}{|c|c|c|c|c|c|}
\hline \multirow[t]{2}{*}{ Compound } & \multirow[t]{2}{*}{$\tau(\mathrm{ns})$} & \multirow{2}{*}{$\frac{\phi_{\mathrm{F}}}{k_{\mathrm{R}}\left(\mathrm{s}^{-1}\right)}$} & \multirow{2}{*}{$\frac{\phi_{\mathrm{ISC}}}{k_{\mathrm{isc}}\left(\mathrm{s}^{-1}\right)}$} & \multirow{2}{*}{$\frac{\phi_{\mathrm{IC}}}{k_{\mathrm{ic}}\left(\mathrm{s}^{-1}\right)}$} & \multirow[t]{2}{*}{$\tau_{\mathbf{s}_{x}}(\mathrm{ps})$} \\
\hline & & & & & \\
\hline Chla & $6.0 \pm 0.2$ & $\begin{array}{l}0.32 \\
5.310^{7}\end{array}$ & $\begin{array}{l}0.60 \\
110^{8}\end{array}$ & $\begin{array}{l}0.08 \\
1.310^{7}\end{array}$ & $\approx 5$ \\
\hline [3-acetyl]-Chla & $5.9 \pm 0.2$ & $\begin{array}{l}0.41 \\
6.910^{7}\end{array}$ & $\begin{array}{l}0.49 \\
8.310^{7}\end{array}$ & $\begin{array}{l}0.10 \\
1.710^{7}\end{array}$ & $\approx 50$ \\
\hline$\left[3^{1}-\mathrm{OH}\right]-\mathrm{BChla}$ & $2.9 \pm 0.2$ & $\begin{array}{l}0.23 \\
710^{7}\end{array}$ & $\begin{array}{l}0.67 \\
210^{8}\end{array}$ & $\begin{array}{l}0.10 \\
3.410^{7}\end{array}$ & $\approx 50$ \\
\hline [3-vinyl]-BChla & $3.1 \pm 0.2$ & $\begin{array}{l}0.20 \\
6.510^{7}\end{array}$ & $\begin{array}{l}0.75 \\
2.410^{8}\end{array}$ & $\begin{array}{l}0.05 \\
1.610^{7}\end{array}$ & $\approx 5$ \\
\hline BChla & $3.0 \pm 0.2$ & $\begin{array}{l}0.19 \\
6.310^{7}\end{array}$ & $\begin{array}{l}0.76 \\
2.510^{8}\end{array}$ & $\begin{array}{l}0.05 \\
1.710^{7}\end{array}$ & $\approx 10$ \\
\hline
\end{tabular}




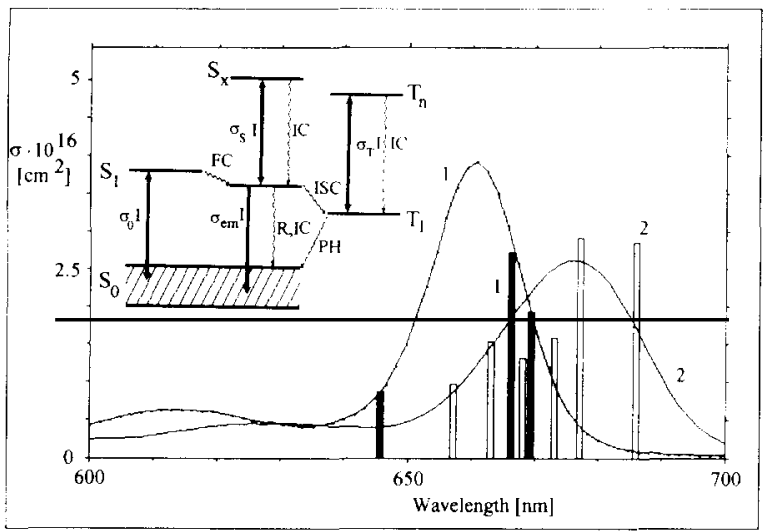

Fig. 1. Cross-sections of the excited singlet absorption $\sigma_{\mathrm{S}}$ (bar graph) in comparison to the ground-state absorption crosssections $\sigma_{0}$ (curves) for (1) Chla and (2) [3-acetyl]-Chla in diethylether at room temperature; Chla: $c=1 \times 10^{6} \mathrm{M}$, [3acetyl]-Chla: $c=2.5 \times 10^{-6} \mathrm{M}$; inset: energy level scheme for simulation of nonlinear absorption curves ( $\mathrm{cf}$. text).

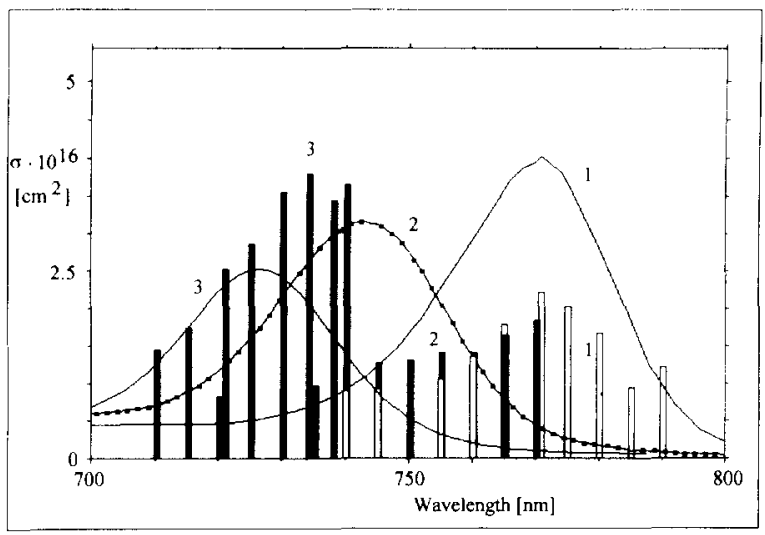

Fig. 2. Cross-sections of the excited singlet absorption $\sigma_{\mathrm{s}}$ (bar graph) in comparison to the ground-state absorption crosssections $\sigma_{0}$ (curves) for (1) BChla, (2) [3-vinyl]-BChla and (3) $\left[3^{1}-\mathrm{OH}\right]-\mathrm{BChla}$ in diethylether at room temperature; BChla: $r=4.4 \times 10^{-6} \mathrm{M}$. [3-vinyl]-BChla: $c=2.9 \times 10^{-6} \mathrm{M}$. [3 $\left.3^{1}-\mathrm{OH}\right]-$ BChla: $c=2.6 \times 10^{-6} \mathrm{M}$.

Strong excited-state absorptions in the region of the ground-state absorption band could be found for all pigments investigated (cf. Figs. 1 and 2). The calculated values for the relaxation of the $S_{x}$ level $\left(\tau_{\mathbf{S}_{x}}\right)$ are included in Table 1.

\section{Conclusions}

The radiative lifetimes for the series Chla $\rightarrow$ [3-acetyl]-Chla $\rightarrow\left[3^{1}-\mathrm{OH}\right]$-BChla $\rightarrow[3$-vinyl $]$ $\mathrm{BChla} \rightarrow$ Bchla are almost equal. However, the fluorescence lifetimes decrease in this order and the differences are mainly related to the presence or absence of a fully unsaturated ring $B$. With exception of [3-acetyl]-Chla this correlates with increased ISC. For all compounds strong excitedstate absorptions within the $\mathrm{S}_{0} \rightarrow \mathrm{S}_{1}$ absorption band were found.

\section{Acknowledgement}

This work was supported by the Deutsche Forschungsgemeinschaft (Le 729/1-1, Sche 140/13-1).

\section{References}

[1] D. Leupold, A. Struck, H. Stiel, K. Teuchner, S. Oberländer and H. Scheer, Chem. Phys. Lett. 170 (1990) 478; A Pfarrherr, K. Teuchner, D. Leupold and P. Hoffmann, J. Photochem. Photobiol. B: Biol. 9 (1991) 35.

[2] M. Becker, V. Nagarjan, D. Meddendorf. M.A. Shield and W.W. Parson, in: Current Research in Photosynthesis. Vol. I, ed. M. Baltscheffsky (Kluwer, Dordrecht, 1990) p. 101.

[3] H. Scheer and A. Struck, in: Photosynthetic Reaction Center, eds. J.R. Norris and J. Deisenhofer (Academic Press, New York), in press.

[4] K. Teuchner, A. Pfarrherr, H. Stiel, W. Freyer and D Leupold, Photochem. Photobiol. 57 (1993) 465.

[5] J.S. Connolly, E.B. Samuel and A.F. Jansen. Photochem. Photobiol. 36 (1982) 565.

[6] H. Stiel, K. Teuchner, W. Becker, Exp. Techn. Phys. 39 (1991) 15; H. Stiel, K. Teuchner, D. Leupold, S. Oberländer. S. Ehlert and R. Jahnke, Intell. Instr. Comp. 9 (1992) 79.

[7] G.P. Gurinovich, A.N. Losev and E.I. Segun, J. Appl. Spectrose. (USSR) 26 (1976) 740. 